Marek URBANIK ${ }^{1}$

\title{
ANALYSIS OF CONSUMER EXPECTATIONS RELATED TO THE SERVICES PROVIDED BY GAS COMPANY
}

\begin{abstract}
The aim of the study was getting an opinion of gas consumers on the functioning of the gas distribution subsystem. The conducted survey concerned the issues related to the assessment of nuisance, the effectiveness of notification and the assessment of losses caused by interruptions in gas supply. The survey also included the satisfaction of the respondents with the quality of services provided by the gas enterprise. An important issue is the assessment of nuisance of gas supply interruptions, their time and frequency, knowledge of the causes, nuisances and losses caused by the lack of gas supply. Additional questions concern, among others, the issues of costs associated with gas consumption, the continuity of gas supply and the required pressure. Customer feedback may be used to determine the compensation for losses resulting from gas supply disruptions. Consumers opinions can be used in determining the standards of gas supply reliability. In turn, the respondents' suggestions are aimed at improving the quality of services provided by the gas company. In order to assess the level of satisfaction and continuously improve the quality of service the gas company should carry out continuous monitoring of satisfaction among gas recipients by conducting surveys among them. The performed research can be very helpful in planning potential modernization of critical infrastructure and to maintain its proper functioning.
\end{abstract}

Keywords: consumers survey, gas infrastructure operation, gas supply, assessment of gas supply.

\section{INTRODUCTION}

One of the basic conditions for the functioning of urban agglomerations in the face of crisis situations or even during normal functioning of gas infrastructure is to ensure safe delivery of gas for consumption through gas infrastructure. The occurrence of undesirable events and processes, as well as their cumulation, can lead to a threat for proper and safe functioning of the system or even to its development. As critical infrastructure includes energy supply, energy resources and fuels, in order to ensure the security of the state and its citizens, its protection should be improved continuously according to the Act of 26 April 2007 on Crisis Management (OJ 2007, No. 89, item 590, as amended) and the Directive 2008/114/EC of identification and designation of European critical infrastructure and assessing the need to improve its protection (EC 345 from 23.12.2008). According to the previously mentioned regulations, critical infrastructure should meet the specified requirements according to such criteria as casualties criterion assessed in terms of the potential 1 Mgr inż. Marek Urbanik, Wydział Budownictwa, Inżynierii Środowiska i Architektury, Politech-
nika Rzeszowska, al. Powstańców Warszawy 6, 35-959 Rzeszów; e-mail: marekurbanik@ @onet.pl. 
number of fatalities or injuries and economic effects criterion assessed in terms of the significance of economic losses and degradation of products or services, also including potential environmental effects ${ }^{2}$. Also important is public effects criterion assessed in terms of the impact on public confidence, physical suffering and disruption of daily life, including the loss of essential services ${ }^{3}$. Also important is public effects criterion assessed in terms of the impact on public confidence, physical suffering and disruption of daily life, including the loss of essential services. Taking into account the last criterion it is important to conduct the survey to find people's opinions on the operation of gas systems, which can help in performing the assessment of quality of service provided by the gas company as gas should reach the recipients at the right time and place, also in the necessary quantity and quality. Studies of critical infrastructure concerning gas resources and gas supply failures are presented in numerous works, among others ${ }^{4}$. Companies supervising critical infrastructure conduct such studies more and more often because thanks to their results they can find a lot of information about the systems functioning which in the future can help improve the quality of services and plan potential modernization of network, as well as maintain the reliable functioning of critical infrastructure ${ }^{5}$ and determine the emergency source of supply ${ }^{6}$.

The results obtained from the conducted studies allow controlling responsible companies and knowledge of recipients dissatisfaction allows to indicate what should be done to improve quality of provided services.

2 B. Tchórzewska-Cieślak, J. Rak, Ryzyko w systemie zaopatrzenia w gaz ziemny (Risk in natural gas supply system), ,Zeszyty Naukowe Politechniki Rzeszowskiej. Budownictwo i Inżynieria Środowiska", 2003, No. 2, pp. 231-242.

3 J. Rak, E. Tułacz, Analiza opinii sondażu użytkowników wodociagów publicznych na temat przerw $w$ dostawie wody (Analysis of consumer reviews of drinking water about lack of water supply), „Zeszyty Naukowe Politechniki Rzeszowskiej. Budownictwo i Inżynieria Środowiska” 2004, No. 2, pp. 337-348.

4 J. Rak, K. Pietrucha-Urbanik, Badanie sondażowe zwiazane z brakiem dostawy wody wodociagowej $w$ sytuacjach kryzysowych (Survey related to lack of water supply water in crisis situations), „Instal” 2016, No. 2, pp. 54-58; J. Rak, Analiza opinii konsumentów wody do spożycia korzystajacych z wodociagu publicznego miasta Rzeszowa (Analysis of consumer reviews of drinking water using the public water network of Rzeszow city), „Technologia Wody” 2012, No. 1, pp. 30-34; J. Rak, E. Tułacz, Analiza opinii konsumentów wody do spożycia korzystających z wodociagu publicznego na terenie województwa podkarpackiego (Analysis of consumer reviews of drinking water using water form network in Podkarpacie), „Zeszyty Naukowe Politechniki Rzeszowskiej. Budownictwo i Inżynieria Środowiska”, 2007, No. 3, pp. 123-136.

5 J. Rak, K. Pietrucha-Urbanik, New directions for the protection and evolution of water supply systems - smart water supply, „Czasopismo Inżynierii Lądowej, Środowiska i Architektury - Journal of Civil Engineering, Environment and Architecture. JCEEA”, 2015, No z. 3/I, pp. 365-373. DOI: 10.7862/rb.2015.121; A. Studziński, K. Pietrucha-Urbanik, Preventive maintenance and reliability of water supply system elements, „Czasopismo Inżynierii Lądowej, Środowiska i Architektury Journal of Civil Engineering, Environment and Architecture, JCEEA”, 2015, No. 3/I, pp. 429-436. DOI: $10.7862 / \mathrm{rb} .2015 .126$.

6 J.R. Rak, Propozycja oceny dywersyfikacji objętości wody w sieciowych zbiornikach wodociagowych (The proposal of diversyfication assessment of water volume in water supply network tanks), „Czasopismo Inżynierii Lądowej, Środowiska i Architektury - Journal of Civil Engineering, Environment and Architecture, JCEEA” 2015, No. 1, pp. 339-349, DOI: 10.7862/rb.2015.23. 
Suppliers should provide services on the proper level as to meet certain legal regulations in order to deliver the medium without interruption and with proper pressure ${ }^{7}$.

The conducted surveys can be a good source of information for supervising companies, also through expressing a degree of customer satisfaction about provided services ${ }^{8}$. It is recommended to form the direct questions in surveys, also form the group of recipients of similar age and gender, as suggested in following works ${ }^{9}$. Also numerous tools can be applied to perform surveys, as recommended in work ${ }^{10}$, as surveys are a valuable source of information for gas companies ${ }^{11}$.

\section{METHODOLOGY OF RESEARCH}

The research concerned individual persons using the gas distribution subsystem. In order to determine the size of the survey sample the size of the allowable error was taken into account ${ }^{12}$. The error margin of the recommended size of the survey sample for a confidence level of $95 \%$ is $3 \%$ for the number of persons 1000 , for the number of persons 300 , the margin of error is $6 \%$, and for the number of persons 200 , the error margin is $7 \%{ }^{13}$. The survey was conducted both through direct interview as well as telephone interview and through a specially created questionnaire via the Internet, in order to reach a large group of respondents in a relatively short time and a diverse group of recipients. The study was conducted in September 2016. A non-random sampling was used in the case of direct interviews, as the sample was selected for the specific network of users of the city's gas distri-

7 B. Tchórzewska-Cieślak, Method of assessing of risk of failure in water supply system. European safety and reliability conference (ESREL), Risk, reliability and societal safety, Taylor \& Francis, 2007, Vol. 2, pp. 1535-1539; B. Tchórzewska-Cieślak, J. Rak, Metoda wyznaczania niezawodności podsystemu dystrybucji gazu ziemengo dla jednostek osadniczych (Method of determining the reliability of the natural gas distribution subsystem for settlement units), „Gaz, Woda i Technika Sanitarna" 2001, No. 12, pp. 222-229; B. Tchórzewska-Cieślak, J. Rak, Analiza modernizacji remontów dystrybucyjnej sieci gazowej na przykładzie miasta Rzeszowa (Analysis of modernization and repaired distributive gas systems based on the example of the city of Rzeszow), ,Zeszyty Naukowe Politechniki Rzeszowskiej. Budownictwo i Inżynieria Środowiska”, 2003, No. 2, pp. 222-229.

8 V.R. Shinde, N. Hirayama, S. Itoh, Development of evaluation model for consumers' satisfaction of water supply service, „WIT Transactions on Ecology and The Environment”, 2014, Vol 178, pp. 215-223, DOI:10.2495/13WS130181.

9 P. Hague, Badania marketingowe. Planowanie, metodologia i ocena wyników (Marketing research. Planning, methodology and evaluation of results), HELION, Gliwice 2006; S. Kaczmarczyk, Badania marketingowe. Metody i techniki (Marketing research. Methods and techniques), PWE, Warszawa 2003

${ }^{10}$ M. Goodyear, Qualitative research, ESOMAR, London 1998; R.J. Kaden, Badania marketingowe (Marketing research), PWE, Warszawa 2008.

11 J. Rak, Zasady badań marketingowych zwiazanych z zaopatrzeniem w wodę (Principles of marketing research related to water supply), „Wodociągi-Kanalizacja” (Sewerage-Water Supply Systems), 2005, No. 5(14), pp. 13-16.

${ }^{12}$ S. Kaczmarczyk, Badania marketingowe...

${ }^{13}$ M. Szewczyk, M. Ciesielska, Podstawy statystyczne badan marketingowych (Statistical basics of marketing research), Publisher Opole University of Technology, Opole 2010; W.O. Bearden, R.G. Netemeyer, Handbook of Marketing Scales. Sage Publications, London 1999. 
bution subsystem ${ }^{14}$. In the case of the Internet and telephone research, simple random selection and the so-called comfortable selection were used.

The survey consisted of an even number of respondents on the basis of sex of the respondents, who participated in the study. The study included an even number of respondents of the same sex. Also, a comparable age structure was established. Among the surveyed $45 \%$ of people have technical education or technical professions, the rest has the so-called non-technical and general education. According to the respondent's place of residence, the structure was as follows: multi-storey blocks about $45 \%$ of respondents, tenement house $19 \%$ of respondents, family houses $-36 \%$ of respondents. The research was conducted in the form of a survey questionnaire for about two hundred recipients and presented in the form of 21 questions.

In the last part of the questionnaire there is the metrics containing seven questions concerning education, occupation, age and area of the respondent residence, the number of people residing in the surveyed household, in order to determine the unit gas consumption in the individual households, and the optional question about income. The aim of the metrics is to verify if the tested sample is similar to the whole population ${ }^{15}$.

The questionnaire contained both closed questions and open questions so that the respondent could additionally comment the given subject. The questions were both open and closed, either of single or multiple choice. For each question a set of answers was formulated in a way that does not exclude the other questions, the so-called cafeteria questions. Prior to the survey, people who did not have knowledge of the subject were eliminated from the study ${ }^{16}$. The results of the performed survey can be compared with the results of previous studies taking into account the respondents' attitude from different groups. The reference point can be almost any indicator, as well as the applicable legal regulations and industry standards or comparison of available concepts and different target segments of comparative analysis ${ }^{17}$.

The questionnaire survey was performed through the software package Statistica 12.

\section{RESULTS OF RESEARCH}

The first question concerned the assessment of the quality of services provided by the gas company. The activity of the gas company was assessed on the basis of the question about satisfaction or dissatisfaction with the quality of services provided by the gas company. After performed analysis, $65 \%$ of respondents were satisfied with the provided services by gas company, on the other hand, $15 \%$ of respondents reported dissatisfaction with

${ }^{14}$ T. Kramer, Podstawy marketingu (Basics of marketing), PWE, Warszawa 1994; G.A. Churchill, Badania marketingowe (Marketing research), Wydawnictwo Naukowe PWN, Warszawa 2002.

${ }^{15}$ S. Itoh, S. Shiro, N. Hirayama, S. Echigo, Y. Ohkouchi, Psychosocial considerations on strategies for improving customers' satisfaction with tap water based on casual modelling, ,Journal of Japan Water Works Association" 2007, No. 4, pp. 25-37.

16 J. Rak, Zasady badań marketingowych zwiazanych..., pp. 13-16; A. Speers, S. Burn, D.H. MacDonald, B. Nancarrow, G. Syme, M. Young, Determining Customer Service Levels - Development of a Methodology. Overarching Report. BCE Doc. No. 01/199, CSIRO 2002.

${ }^{17}$ M. Walesiak, Metody analizy danych marketingowych (Methods of marketing data analysis); PWN, Warsaw 1996; E. Kieżel, Konsument i jego zachowania na rynku europejskim (Consumer and its behavior on the European market), PWE, Warsaw 2010. 
the quality of services provided by the gas company and $20 \%$ have no opinion. This is not a good situation for the company because there is a high risk that people who do not have any opinion can go to the side of dissatisfied people, therefore the company must constantly improve its service level so that undecided people will be among satisfied people ${ }^{18}$.

$56 \%$ of respondents had contact with the gas company's office, recipients which had contact with the customer service positively assessed the work of its employees, about $83 \%$ indicate the competence, culture and fast service. On the other hand, the negative rating was related to the length of service which, according to the respondents, was associated with a small number of staff serving clients, as shown in ${ }^{19}$.

The respondents participating in the survey were asked to rank the five qualities of supplied gas, using a hierarchy according to the most important qualities. The most important qualities for almost $70 \%$ of respondents were continuity and appropriate pressure of the delivered gas. It can be stated that for the gas recipients more important is quality of delivered gas than a price of supplied gas and low failure rate of gas network.

The conducted survey verifies the research presented $\mathrm{in}^{20}$. Considering the division of consumers into the age groups it can be noted that the most important quality for every group is continuity and the pressure of supplied gas. Examining the pressure of the supplied gas, the majority of respondents (almost 93\%) are satisfied with pressure of gas provided by the gas company, however, there were also those who were not satisfied. Such situation may be due to various factors as failures or leaks in the gas supply network.

The activity of the gas company was also assessed in terms of the way the gas meter was read, with as many as half of the respondents indicating manual readings through the company's employees, the others indicated reading by the Internet via the company's website or about $25 \%$ by email. The Internet readings are mostly preferred by young people, as opposed to traditional reading methods that are opted by older people. Taking into account the satisfaction of the recipients of meter reading almost $90 \%$ of respondents are satisfied with the way of reading the gas meter. On the other hand, the unsatisfied respondents indicated that they would prefer to change to radio readings via telemetry as well as to change to monthly readings, which confirm previous studies ${ }^{21}$.

Recipients were also asked if they submit complaints about not meeting the standards of provided services, about $3 \%$ of respondents placed such complaint during three years. In comparison to survey performed by the Ofgem and GfK Energy Research Panel, which

${ }^{18}$ S. Itoh, S. Shiro, N. Hirayama, S. Echigo, Y. Ohkouchi, Psychosocial considerations..., pp. 25-37.

19 J. Rak, Zasady badań marketingowych związanych..., pp. 13-16; J. Rak, E. Tułacz, Analiza opinii konsumentów wody do spożycia korzystających z wodociagu publicznego na terenie województwa podkarpackiego (Analysis of consumer reviews of drinking water using water form network in Podkarpacie), ,Zeszyty Naukowe Politechniki Rzeszowskiej. Budownictwo i Inżynieria Środowiska”, 2007, No. 3, pp. 123-136.

20 A. Wieczysty, P. Krawczyk, Ocena uciążliwości przerw w dostawie wody przez jej odbiorców (Assessment of the nuisance of water supply interruptions by its recipients). Conf. Proc. of II Conf. „Safety, reliability, diagnostics equipment and systems of gas, water, sewage and heating”, Publisher PZITS O/Cracow, 2001, No. 797, Zakopane, pp. 409-417.

${ }^{21}$ Energy Community Regulatory Board, Survey on the status quo of gas billing practices in the Energy Community, December 2011, https://www.energy-community.org/dam/jcr:d515927b4a76-4d2b-ba39-2a45d73208c3/ECRB_survey_status_quo.pdf. [access 11.2017]. 
compare supplier performance on customer service, about $26 \%$ complaints were received by the largest supplier ${ }^{22}$.

The functioning of gas companies in terms of the quality of gas supply service was also rated by respondents for the effectiveness of the notification of interruptions in gas supply. More than $76 \%$ of respondents stated that used information method was effective. The large percentage of respondents $(73.6 \%)$ are informed about lack of gas supply in the form of the written notification. Quite large groups are the respondents who do not get the information which can be a reason of low assessment of the notification effectiveness of interruptions of the gas supply. Interruptions in the gas supply can cause various inconveniences if occur during the day, therefore respondents were asked to indicate the hours of the day in which they are most disturbed by the lack of gas supply. The biggest nuisance, according to respondents, causes gas supply disruptions occurring in the evening from 5 to 8 p.m, it may be due to the fact that respondents are at home at those hours. Therefore during this period of time any planned repair of the gas supply system (except for sudden failures) should not be performed.

Very important issue is the assessment of lack of supply medium through the critical infrastructure ${ }^{23}$, therefore respondents were also asked what inconveniences are occurring during gas supply interruptions. The most common responses indicate heating and preparation of hot gas needed for personal hygiene, preparing meals during breaks in gas supply, other responses were associated with the performance of domestic work, including dishwashing. As people perform these activities when they are present at home so the natural thing is that break in gas supply is the most inconvenient during free days and holidays.

Assessing the hierarchy nuisance of frequency interruptions in gas supply, it was stated that three daily interruption of gas supply once a year for $73 \%$ of the respondents were defined as high nuisance, the break from 2 to 4 hours per year, by $85 \%$ of respondents were identified as very small.

The next examined issue concerns the opinion of consumers about the losses resulting from interruptions in gas supply and the need for compensation. Only $15 \%$ of respondents believe that a gas supply break causes some financial loss to their household, compared to $85 \%$ of respondents who think that a break in gas supply does not cause financial losses. Respondents who believe that gas supply disruptions are generating financial losses justify it by the need to reorganize planned work, difficulty in preparing meals and necessity to introduce some corrective actions to ensure proper temperature in rooms and the preparation of ready-to-use gas. Also the customers indicate, that financial losses connected with break in the gas supply can be connected with the change of way of heating and preparing hot gas, which is connected with increased charges for the alternative source of energy, in this case, for example, electricity.

${ }^{22}$ GfK Energy Research Panel, Annual Customer Satisfaction Survey Results http://www.gfk.com/industries/energy/[acess 11.2017].

${ }^{23}$ V.R. Shinde, N. Hirayama, S. Itoh, Development of evaluation model for consumers' satisfaction of water supply service, ,WIT Transactions on Ecology and The Environment” 2014, Vol. 178, pp. 215-223, DOI: 10.2495/13WS130181; A. Wieczysty, P. Krawczyk, Ocena uciążliwości..., pp. 409-417. 


\section{CONCLUSIONS}

Gas companies should perform a survey among their recipients, as measure to assess proper functioning of gas supply systems, which is expressed, among others, by the social feeling.

Surveys of consumer opinion help to provide an indicative view of the perceptions of consumers about interruptions of gas supply. The results of the questionnaire will allow better adjustment of the gas supply conditions in the face of undesirable events concerning everyday life or even danger to life.

In order to effectively ensure the safety of gas supply systems, it is necessary to perform dialogue concerning the public opinion, thus developing opportunities for effective action during undesirable events. The proposed survey will provide information on gas supply and will be helpful in developing prevention strategy for undesirable events in gas supply systems.

Properly developed strategies for improving the functioning of the services provided by gas companies include survey studies related to the lack of gas supply.

It contributes to the safe operation of gas supply systems and constitutes a key element allowing planning effective procedure to ensure safety way of gas supply to the recipients.

\section{REFERENCES}

[1] Bearden W.O., Netemeyer R.G., Handbook of Marketing Scales. Sage Publications, London 1999.

[2] Churchill G.A., Badania marketingowe (Marketing research). Wydawnictwo Naukowe PWN, Warszawa 2002.

[3] Energy Community Regulatory Board, Survey on the status quo of gas billing practices in the Energy Community, December 2011, https://www.energy-community.org/dam/jcr: d515927b-4a76-4d2b-ba39-2a45d73208c3/ECRB_survey_status_quo.pdf. [acess 11.2017].

[4] GfK Energy Research Panel, Annual Customer Satisfaction Survey Results http://www. gfk.com/industries/energy/ [acess 11.2017].

[5] Goodyear M., Qualitative research, ESOMAR, London 1998.

[6] Hague P., Badania marketingowe. Planowanie, metodologia i ocena wyników (Marketing research. Planning, methodology and evaluation of results), HELION, Gliwice 2006.

[7] Itoh S., Shiro S., Hirayama N., Echigo S., Ohkouchi Y., Psychosocial considerations on strategies for improving customers' satisfaction with tap gas based on casual modelling, „Journal of Japan Gas Works Association” 2007, No. 4.

[8] Kaczmarczyk S., Badania marketingowe. Metody i techniki (Marketing research. Methods and techniques), PWE, Warszawa 2003.

[9] Kaden R.J., Badania marketingowe (Marketing research), PWE, Warszawa 2008.

[10] Kieżel E., Konsument i jego zachowania na rynku europejskim (Consumer and its behavior on the European market), PWE, Warsaw 2010.

[11] Kramer T., Podstawy marketingu (Basics of marketing), Polskie Wydawnictwo Ekonomiczne, Warszawa 1994.

[12] Rak J., Analiza opinii konsumentów wody do spożycia korzystajacych z wodociagu publicznego miasta Rzeszowa (Analysis of consumer reviews of drinking gas using the public gas network of Rzeszow city), ,Technologia Wody”, 2012, No. 1. 
[13] Rak J., Pietrucha-Urbanik K. New directions for the protection and evolution of gas supply systems - smart gas supply, „Czasopismo Inżynierii Lądowej, Środowiska i Architektury Journal of Civil Engineering, Environment and Architecture. JCEEA”, 2015, No. z. 3/I, DOI: 10.7862/rb.2015.121.

[14] Rak J., Pietrucha-Urbanik K., Badanie sondażowe zwiąane z brakiem dostawy wody wodociagowej w sytuacjach kryzysowych (Survey related to lack of gas supply gas in crisis situations), „Instal” 2016, No. 2.

[15] Rak J., Tułacz E., Analiza opinii konsumentów wody do spożycia korzystających z wodociagu publicznego na terenie województwa podkarpackiego (Analysis of consumer reviews of drinking gas using gas form network in Podkarpacie), „Zeszyty Naukowe Politechniki Rzeszowskiej. Budownictwo i Inżynieria Środowiska”, 2007, No. 3.

[16] Rak J., Tułacz E., Analiza opinii sondażu użytkowników wodociagów publicznych na temat przerw $w$ dostawie wody (Analysis of consumer reviews of drinking gas about lack of gas supply), „Zeszyty Naukowe Politechniki Rzeszowskiej. Budownictwo i Inżynieria Środowiska" 2004, No. 2.

[17] Rak J., Zasady badań marketingowych zwiazanych z zaopatrzeniem w wodę (Principles of marketing research related to gas supply), „Wodociągi-Kanalizacja” (Sewerage-Gas Supply Systems) 2005, No. 5(14).

[18] Rak J.R., Propozycja oceny dywersyfikacji objętości wody w sieciowych zbiornikach wodociagowych (The proposal of diversyfication assessment of gas volume in gas supply network tanks). „Czasopismo Inżynierii Lądowej, Środowiska i Architektury - Journal of Civil Engineering, Environment and Architecture, JCEEA", 2015, No. 1, DOI: 10.7862/rb.2015.23.

[19] Shinde V.R., Hirayama N., Itoh S., Development of evaluation model for consumers' satisfaction of gas supply service. „WIT Transactions on Ecology and The Environment”, 2014, Vol. 178, DOI:10.2495/13WS130181.

[20] Speers A., Burn S., MacDonald D.H., Nancarrow B., Syme G., Young M., Determining Customer Service Levels - Development of a Methodology. Overarching Report. BCE Doc. No. 01/199, CSIRO 2002.

[21] Studziński A., Pietrucha-Urbanik K., Preventive maintenance and reliability of gas supply system elements. „Czasopismo Inżynierii Lądowej, Środowiska i Architektury - Journal of Civil Engineering, Environment and Architecture, JCEEA", 2015, No. 3/I, DOI: 10.7862/rb.2015.126.

[22] Szewczyk M., Ciesielska M., Podstawy statystyczne badań marketingowych (Statistical basics of marketing research). Publisher Opole University of Technology, Opole 2010.

[23] Tchórzewska-Cieślak B., Method of assessing of risk of failure in gas supply system. European safety and reliability conference (ESREL), Risk, reliability and societal safety, Taylor \& Francis, 2007, Vol. 2.

[24] Tchórzewska-Cieślak B., Rak J., Analiza modernizacji remontów dystrybucyjnej sieci gazowej na przyktadzie miasta Rzeszowa (Analysis of modernization and repaired distributive gas systems based on the example of the city of Rzeszow). „Zeszyty Naukowe Politechniki Rzeszowskiej. Budownictwo i Inżynieria Środowiska”, 2003, No 2.

[25] Tchórzewska-Cieślak B., Rak J., Metoda wyznaczania niezawodności podsystemu dystrybucji gazu ziemnego dla jednostek osadniczych (Method of determining the reliability of the natural gas distribution subsystem for settlement units). „Gaz, Woda i Technika Sanitarna”, 2001, No. 12. 
[26] Tchórzewska-Cieślak B., Rak J., Ryzyko w systemie zaopatrzenia w gaz ziemny (Risk in natural gas supply system). „Zeszyty Naukowe Politechniki Rzeszowskiej. Budownictwo i Inżynieria Środowiska”, 2003, No. 2.

[27] Walesiak M., Metody analizy danych marketingowych (Methods of marketing data analysis), PWN, Warsaw 1996.

[28] Wieczysty A., Krawczyk P., Ocena uciążliwości przerw w dostawie wody przezjej odbiorców (Assessment of the nuisance of gas supply interruptions by its recipients). Conf. Proc. of II Conf. ,Safety, reliability, diagnostics equipment and systems of gas, gas, sewage and heating”. Publisher PZITS O/Cracow, 2001, No. 797, Zakopane.

\section{ANALIZA OCZEKIWAŃ KONSUMENTA ZWIAZANYCH Z USŁUGAMI DOSTARCZONYMI PRZEZ ZAKŁADY GAZOWE}

Celem badania było poznanie opinii odbiorców gazu na temat funkcjonowania podsystemu dystrybucji gazu. Przeprowadzone badanie sondażowe dotyczyło zagadnień związanych z oceną uciążliwości, skuteczności powiadomienia oraz oceną strat spowodowanych przez przerw $\mathrm{w}$ dostawie gazu. W badaniu sondażowym uwzględniono również ocenę zadowolenia ankietowanych z jakości świadczonych usług przez zakład gazowy. Istotny zagadnieniem jest ocena przez respondentów uciążliwości przerw w dostawie gazu, czasu oraz częstotliwości, znajomości przyczyn, uniedogodnień oraz strat, jakie powoduje brak dostawy gazu. Dodatkowa problematyka pytań dotyczy między innymi kosztów związanych z zużyciem gazu, a także oceny ciągłości dostaw gazu do ich odbiorców oraz wymaganego ciśnienia. Zebrane opinie odbiorców moga znaleźć zastosowanie przy wyznaczaniu rekompensat za straty wynikłe z przerw w dostawie gazu. Opinie konsumentów mogą być stosowane przy określaniu standardów niezawodności dostawy gazu. Z kolei sugestie respondentów mają na celu poprawę jakości świadczonych usług przez zakład gazowy. Dodatkowa tematyka pytań dotyczyła między innymi sposobu wykorzystania oraz zużycia gazu ziemnego. W celu przeprowadzania oceny poziomu satysfakcji oraz stałego podnoszenia jakości usług, zakłady gazowe powinny prowadzić ciągły monitoring zadowolenia wśród obiorców gazu poprzez przeprowadzanie wśród nich sondaży. Przeprowadzone badania mogą być bardzo pomocne $\mathrm{w}$ planowaniu potencjalnych modernizacji infrastruktury i utrzymania jej prawidłowego funkcjonowania.

Słowa kluczowe: badania sondażowe, eksploatacja infrastruktury gazowej, zaopatrzenie w gaz, ocena dostaw gazu.

DOI:10.7862/rz.2017.hss.39

Przestano do redakcji: luty $2017 \mathrm{r}$. Przyjęto do druku: czerwiec 2017 r. 
